\title{
Reproductive Biology of the Dusky Grouper Epinephelus marginatus (LOWE, 1834)
}

\author{
Áthila Bertoncini Andrade ${ }^{1 *}$, Leonardo Francisco Machado ${ }^{1}$, Maurício Hostim-Silva ${ }^{1}$ and \\ João Pedro Barreiros ${ }^{2}$ \\ ${ }^{1}$ Universidade do Vale do Itajaí; Centro de Ensino Superior de Ciências Tecnológicas da Terra e do Mar; \\ R. Uruguai 458; 360 88302-202 Itajaí - SC - Brazil. ${ }^{2}$ Universidade dos Açores; Departamento de Ciências \\ Agrárias; 9701-851; Angra do Heroísmo - Portugal
}

\begin{abstract}
Investigations were carried out about the reproductive biology of the dusky grouper, Epinephelus marginatus (Lowe, 1834) a serranid protogynous hermaphrodite fish inhabitant of rocky bottoms from shallow waters up to 200 $m$ depth. Samples were caught in the islands that form Arvoredo Biological Marine Reserve (SC - Brazil) and the coastal islands near Florianópolis region from March 1998 to May 2000. Data from samples of juvenile groupers on intertidal pools were used to link their occurrence in the pools to the post-spawning season. To describe the histological changes on gonads along the reproductive cycle and to establish maturation scales, 109 groupers were histologically tested for sex determination. First maturation size was determined for females $\left(L_{50}=470 \mathrm{~mm}\right.$; $\left.r^{2}=0.99\right)$. The results of calculated gonadosomatic (GSI) and hepatosomatic (HSI) indexes, showed that maturation occurred along the spring months and the spawning activity during the summer with a peak in December. Liver recovery (HSI elevation) was evident in the autumn, was the post spawning season. The relationship between length and weight was $W=9 \cdot 10^{-6} \cdot T L^{3.1149}\left(r^{2}=0.998 ; n=246\right)$.
\end{abstract}

Key words: Reproduction, Dusky Grouper, Epinephelus marginatus, Santa Catarina, Brazil

\section{INTRODUCTION}

The Dusky grouper, Epinephelus marginatus (Lowe, 1834) (Serranidae, Epinephelinae), inhabits rocky bottoms, from shallow waters to depths of more than 200 meters and lives in caves of stone blocks (Tortonese, 1986). It is a wellknown teleost fish widely distributed along the southern coast of Brazil and also throughout the Mediterranean and the eastern Atlantic from the British Isles to South Africa, Azores, Madeira, Canaries and Cape Verde (Barreiros, 1995). It is a proterogynous hermaphrodite. In Europe, it occurs when individuals are 14-17 years old and about 80-90 cm long (total length) (Bruslé and Bruslé, 1975, 1976; Bou-Ain, 1984; Chauvet, 1991; Garcia, 1996; Barreiros, 1998). Besides its ecological importance, it has an important economic role for artisanal fisheries along Santa Catarina's coast (Medeiros et al. 1997), and is also an emblematic species for spearfishing and scuba diving. The aims of this work were to examine the reproductive biology of the Dusky Grouper and describe the stages of gonad maturation, maturity size in females, and provide information on seasonality of spawning.

\footnotetext{
* Author for correspondence
} 

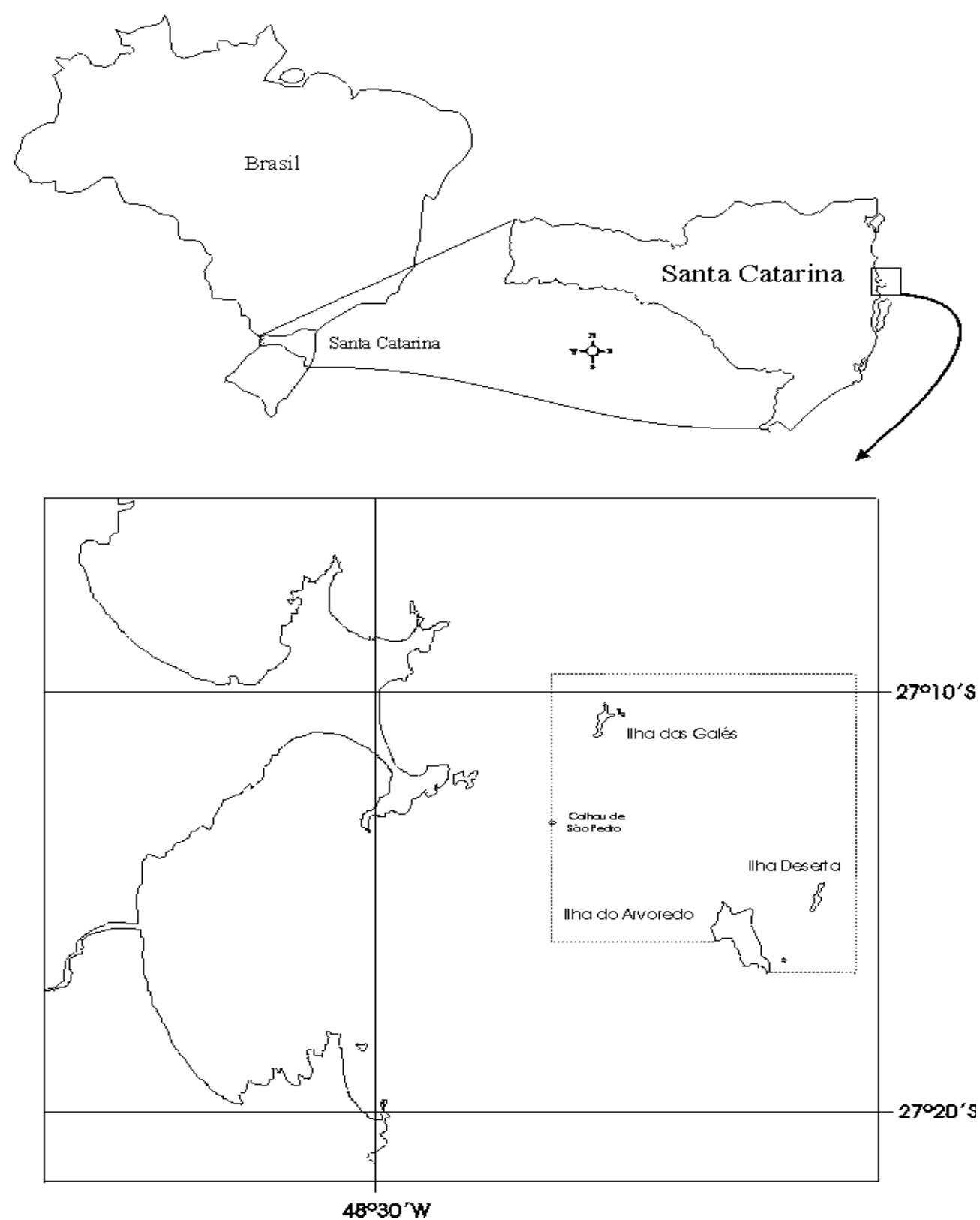

Figure 1 - Localization of Arvoredo Biological Reserve.

\section{MATERIALS AND METHODS}

Specimens were collected from March 1998 through May 2000, monthly in the Arvoredo Biological Marine Reserve (Fig. 1), and also along the coastal islets (Xavier, Campeche and Moleques do Norte) of Santa Catarina Island. Samples were collected by spearfishing methods, which are known to make species selection easier (Derbal and Kara, 1996; Barreiros and Santos, 1998).
Some specimens were obtained from fish markets from the long line fleet that operates along Laguna's coast, south of Santa Catarina State.

Groupers in tidal pools were collected using aquarium nets and acetone diluted Chinaldin ${ }^{\circledR}$, a potent anaesthetic (Gibson, 1967; 1999), to correlate their occurrence with the spawning season.

Specimens were subjected to sex determination, measured for length to the nearest milimeter (Total 
length - TL and Standard length - SL), and weighed with a precision of $0.01 \mathrm{~g}$. After removing gonads, they were preserved in $10 \%$ formaldehyde for a week, and then transferred to $70 \%$ alcohol. Sections were taken from the proximal, medial and distal parts of one gonadal lobe, embedded in paraplastic, sectioned transversely at 5-7 $\mu \mathrm{m}$, and stained with "Harris" hematoxylin and eosin. Each tissue sample was examined microscopically to determine reproductive state. Gonad's classification was adapted based on the gonad development criteria of Vazzoler (1996), Lourinho (1998) and Silveira (1999). Maturity of individual ovaries was based on the most advanced type of oocyte present, regardless of their abundance. Males were classified based on the male gametogenic stages present in the testis and the development of the sperm duct. Length at which $50 \%$ of the females in the population reached sexual maturity was estimated by determining the inflection point of a logistic function fit to the female maturity and length data.

Gonadosomatic indexes (GSI) were calculated as $\mathrm{GSI}=(\mathrm{GW} /(\mathrm{TW}-\mathrm{GW})) \times 100$, where $\mathrm{GW}=$ gonad weight $(\mathrm{g})$ and $\mathrm{TW}=$ total fish weight $(\mathrm{g})$. Hepatosomatic indexes (HIS) were calculated as HIS $=(\mathrm{LW} / \mathrm{TW}) \times 100$, where $\mathrm{LW}=$ liver weight $(\mathrm{g})$ and $\mathrm{TW}=$ total fish weight $(\mathrm{g})$.

\section{RESULTS and DISCUSSION}

A total of 139 specimens was collected. Samples of gonads from 109 fishes ranging from 197 to $1002 \mathrm{~mm}$ (TL) were collected (Fig. 2). Males varied from 800 to $1002 \mathrm{~mm}$ (mean=960 mm, $\mathrm{SD}=75.4, \mathrm{n}=5$ ) and were significantly longer than females, which ranged from 175 to $795 \mathrm{~mm}$ $($ mean=423.5 mm, SD=130.0, $\mathrm{n}=104) \quad(\mathrm{p}<0.01)$. Lengths were divided in classes of $50 \mathrm{~mm}$ (considering the higher limit), and a maximum of 23 fishes for the $400 \mathrm{~mm}$ class was observed. Juveniles from tidal pools varied from 22 to 146 $\mathrm{mm}$ (mean=39 mm, SD=35.2, $\mathrm{n}=107$ ).

The length/weight relationship obtained for the grouped data of sexed groupers and juveniles from tidal pool was $\mathrm{TW}=9 \times 10^{-6} \times \mathrm{TL}^{3.1149}\left(\mathrm{r}^{2}=0.9985\right.$ $n=246$ ) (Fig. 3). Although the value of the exponent "b" (3.1149) of the relation above was similar to the ones found by Kara and Derbal (1995) and Chauvet $(1981,1988)$, a value of $b=2.598$ (probably influenced by the small sample size, $n=22$ ) was obtained by Bouchereau et al. (1999) for the groupers in the Natural Marine Reserve of Lavezzi Islands.

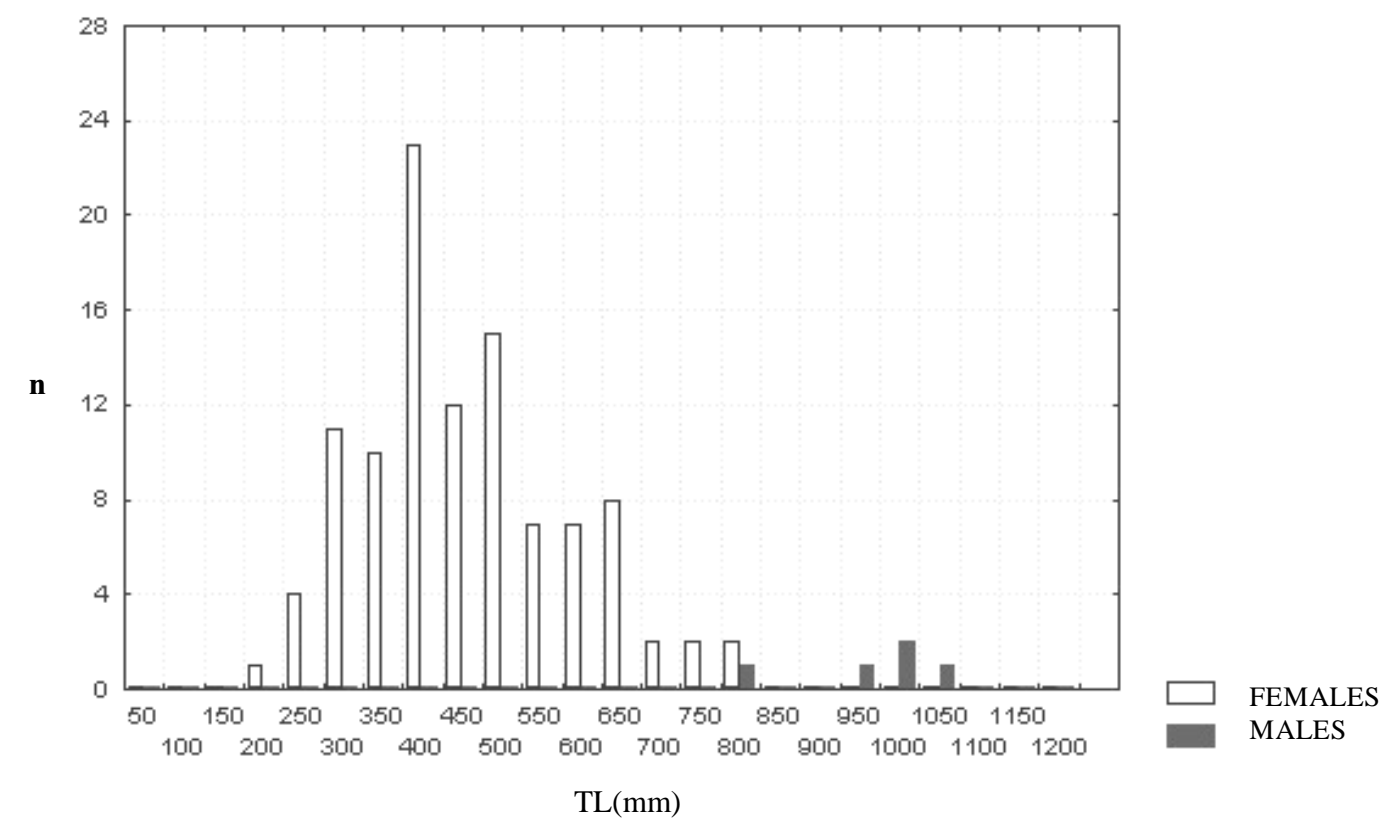

Figure 2 - Length frequencies distribution for the sexed groupers $(n=109)$. 


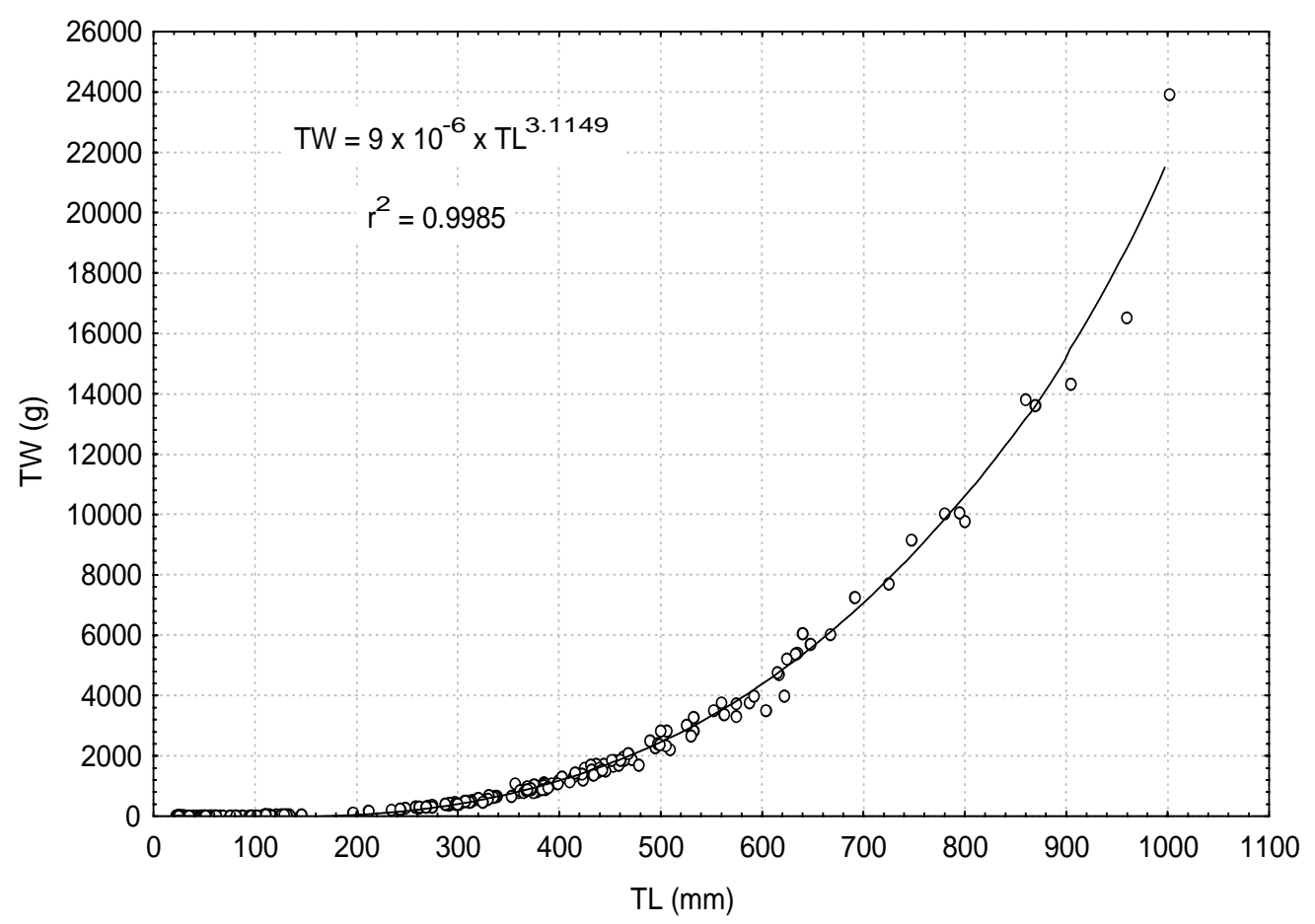

Figure 3 - Length/weight relationship for E. marginatus.

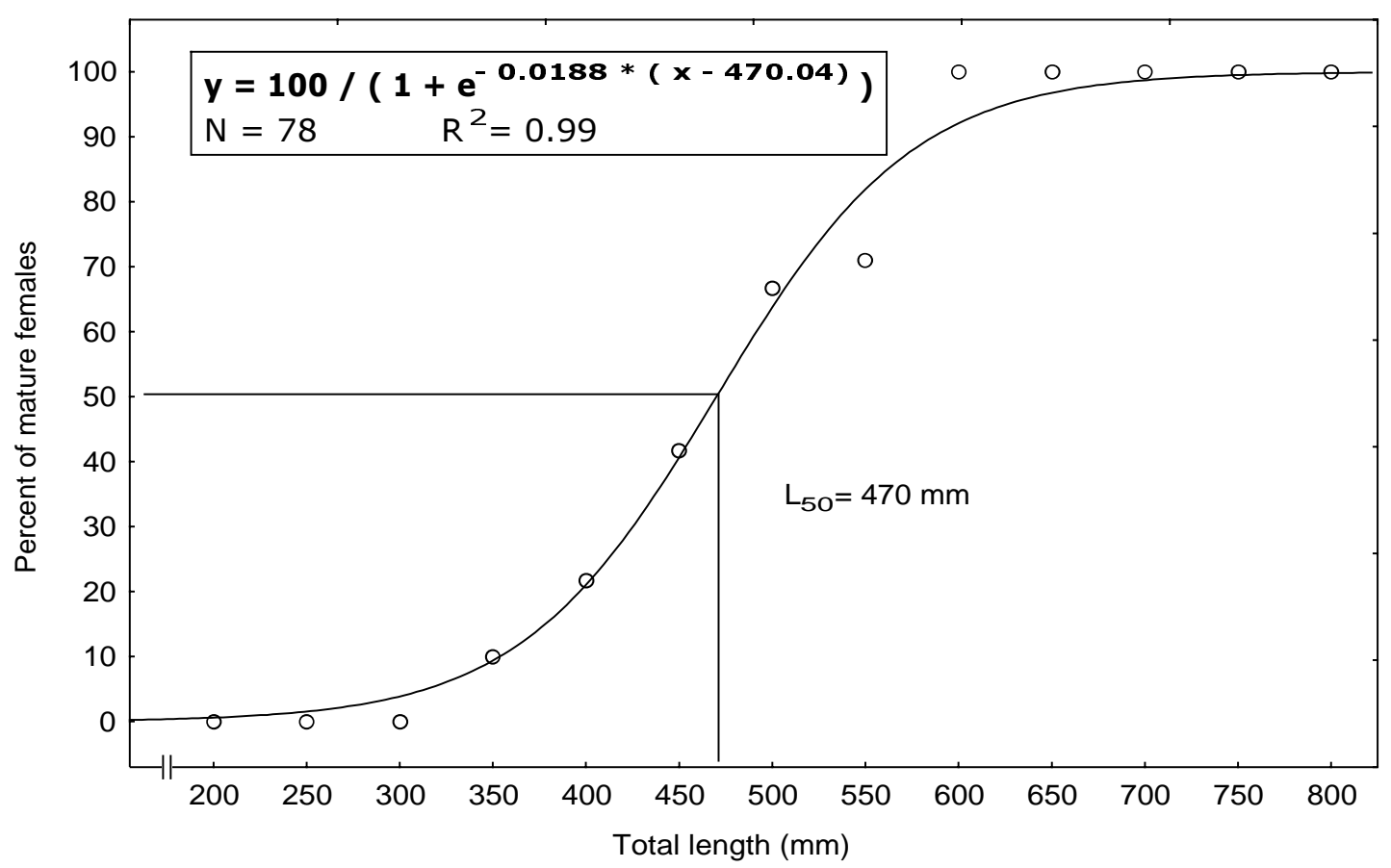

Figure 4 - First maturation curve for E. marginatus. 
First maturation curve presented a characteristic shape typical of species that reached higher sizes, higher longevity and slower growth rate, as was the case of E. marginatus. Its maturation process occured along a vast amplitude of lengths (350 to $600 \mathrm{~mm}$ ). The estimated length at which $50 \%$ of the females in the population reached sexual maturity was $470 \mathrm{~mm}$ (Fig. 4), which corresponded to a grouper weighing approximately $2 \mathrm{~kg}$ (Fig. 3 ). The value of $\mathrm{L} 50=470 \mathrm{~mm}$ was within the amplitude found for Tunisian groupers by Chauvet
(1988), where the population studied reached sexual maturity between 450 and $550 \mathrm{~mm}$ total length, with an average age of 5 years.

Size of sexual inversion was not calculated due to an insufficient sample size. Tunisian and Azorean groupers had an inversion size between 800 and 900 mm (Chauvet, 1988; Barreiros, 1998). In our samples the highest female total length was $795 \mathrm{~mm}$ total length and the smallest male was $800 \mathrm{~mm}$.

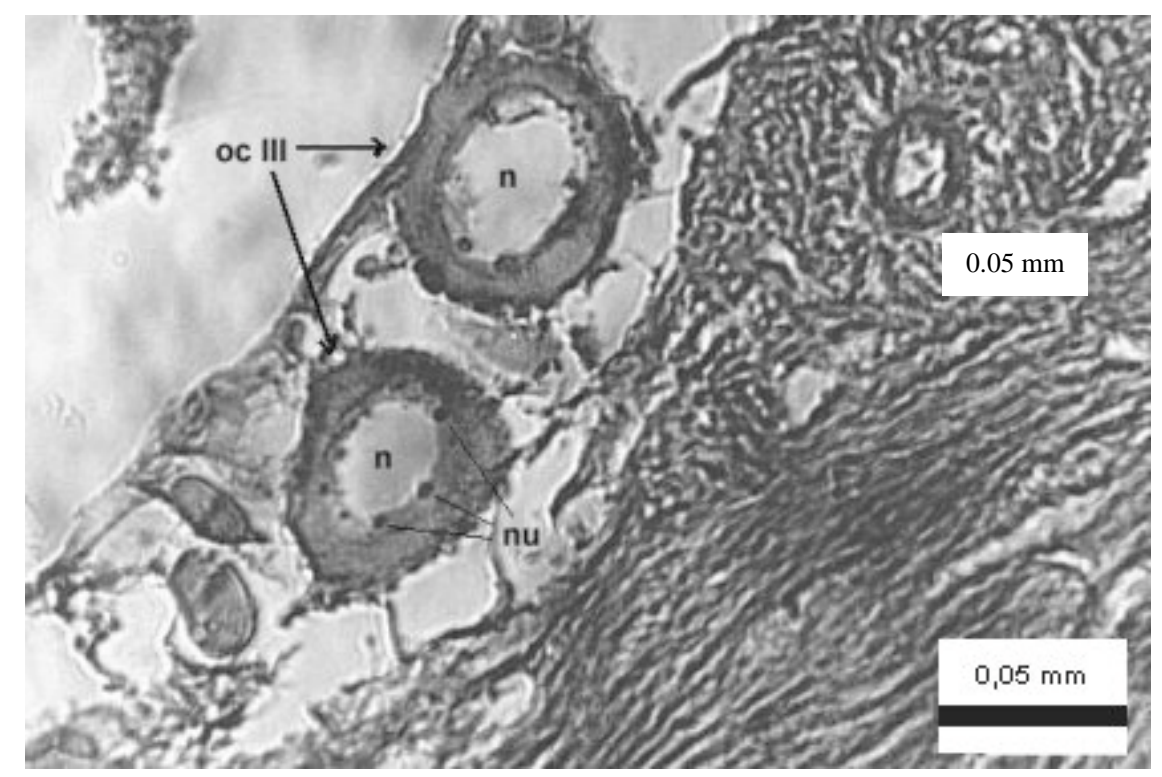

Figure 5 - oocyte 3 (oc III) -advanced perinucleolar stage, n - nucleus, nu - nucleolus. 400x.

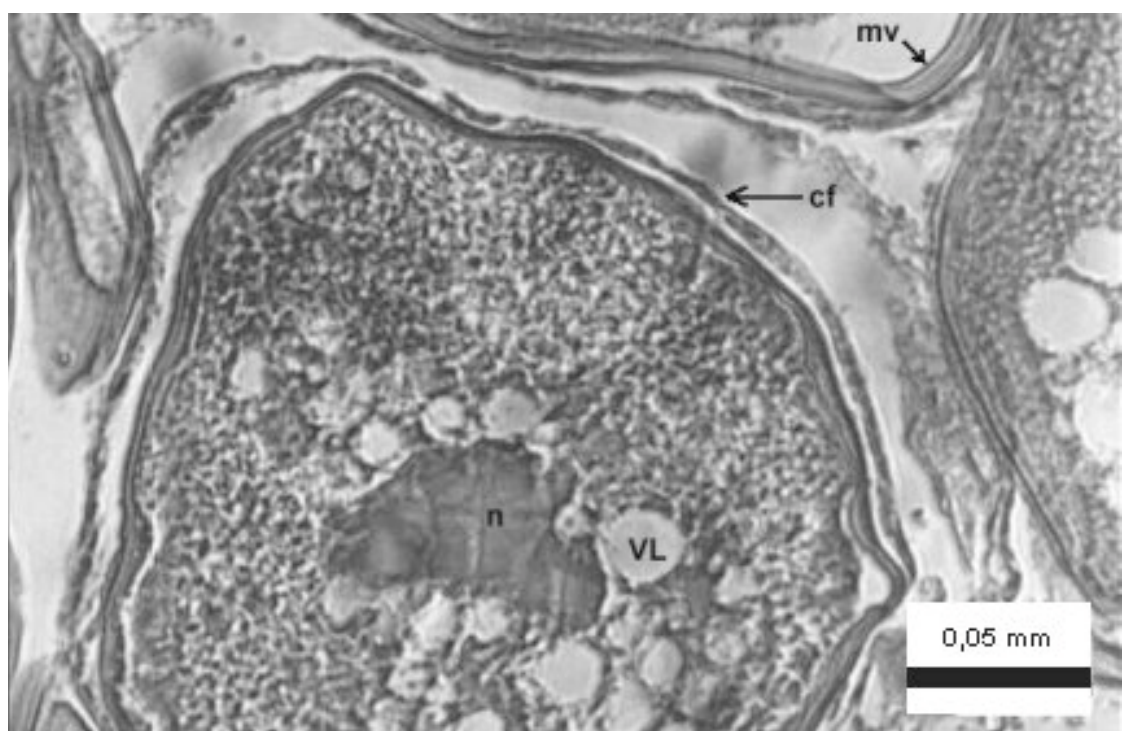

Figure 6 - oocyte 5 - advanced vitellogenic stage. $\mathrm{n}$ - nucleus, VL yolk vesicle, $\mathrm{cf}$ - follicular layer, mv - zona radiata $400 \mathrm{x}$. 
Table 1 - Reproductive classes of E. marginatus gonads defined by characteristic histological criteria.

\section{Females}

(1) Immature Chromatin nucleolar stage (1) (small cells with large nucleus, 1 or 2 nucleolus), and initial perinucleolar stage (2) (bigger oocytes with more than 2 nucleolus) oocytes present. Well-organized aspect.

(2) Mature resting Similar to the previous stage, but with a less organized aspect.

(3) Developing Advanced perinucleolar stage (3) (bigger oocytes with many nucleolus), initial vitellogenic stage (4) (yolk vesicles appear in cytoplasm), advanced vitellogenic stage (5) (appearance of yolk proteins, irregular nucleus shape) oocytes present. Not well-organized aspect.

(4) Developed Completed vitellogenic stage oocytes (6) (yolk vesicles almost not seen). In this stage occurs the peripheral migration of the nucleus and dissolution of its membrane. These oocytes turn into hydrated oocytes (7), by a rapid increase in the size due to hydration of oocytes. Other oocytes are less abundant.

(4) Spent $\quad \begin{aligned} & \text { All seven } \\ & \text { spawning) }\end{aligned}$

\begin{tabular}{ll}
\hline \multicolumn{1}{c}{ Males } & \\
\hline (1) Immature & Crypts with spermatogonia \\
\hline (2) Developing & Crypts with spermatocytes 1 and 2 \\
\hline (3) Late Mature & Spermatids and spermatozoa in the lumen of lobules \\
\hline (4) Ripe & Sperm duct filled with spermatozoa
\end{tabular}

Table 2 - Indexes results with standard deviation (SD).

\begin{tabular}{|c|c|c|c|c|c|}
\hline season & $\mathbf{N}$ & GSI & HSI & SD GIS & SD HSI \\
\hline summer & 53 & 0.180 & 1.286 & 0.209 & 0.788 \\
\hline autumn & 43 & 0.091 & 1.412 & 0.081 & 0.694 \\
\hline winter & 4 & 0.130 & 1.270 & 0.048 & 0.354 \\
\hline spring & 9 & 0.140 & 0.775 & 0.472 & 0.238 \\
\hline
\end{tabular}

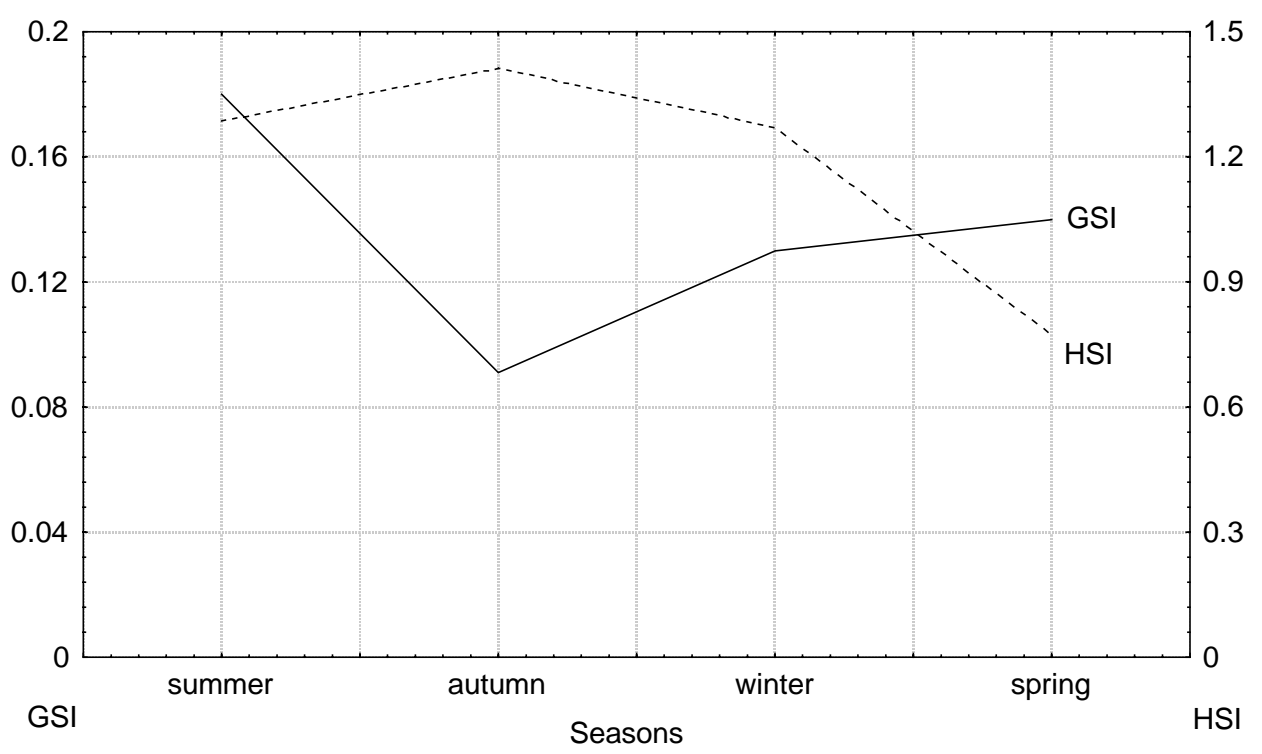

Figure 7 - Gonadosomatic index (GSI) and hepatosomatic index (HSI) for E. marginatus along the seasons. 
Microscopic gonad stages are presented in Table 1. Some oocytes stages are presented in Fig. 5 and 6. Close attention should be given to male classification, not only because its finer classification was difficult and subjective, but also because of our low sample size.

For a better resolution of the indexes results, data were grouped in four seasons (Table 2). The number of sexed groupers, mean TL and standard deviation were respectively: in summer $(n=53$, mean $\mathrm{TL}=423.6, \mathrm{SD}=127.9)$, autumn $(\mathrm{n}=43$, mean $\mathrm{TL}=451.5, \quad \mathrm{SD}=149.5)$, winter $\quad(\mathrm{n}=4, \quad$ mean $\mathrm{TL}=740.5, \mathrm{SD}=262.9)$ and spring: $(\mathrm{n}=9$, mean $\mathrm{TL}=617.7, \quad \mathrm{SD}=259.2$ ). Median gonadosomatic index (GSI) showed the values in summer, decreasing in autumn and getting higher along winter and spring highest. The hepatosomatic index (HSI) plotted showed an inverse pattern of these values in comparison to GSI indexes (Fig. 7).

This behavior suggested that E. marginatus matured in spring and spawned in early summer, with a peak in December. It showed an evident liver recovery (high HSI level) in autumn. Data on juvenile grouper in intertidal areas were found to occur in tidepools from December up to March (Bertoncini et al., 1999), with TL's ranging from 20 to $30 \mathrm{~mm}$, peaking in February and March. Azevedo et al. (1995) suggested that these intertidal pools have an important role as nursery areas for E. marginatus. Heemstra AND Randall (1993) reported that Epinephelus septemfasciatus, a species reaching sizes similar to E. marginatus, reached $30.8 \mathrm{~mm}$ in 60 days after spawning in laboratory conditions. These data reinforced the results showed by the indexes presented above.

Hermaphrodite fishes present age and sexual inversion rates, which are characteristic of a specific geographic region. Chauvet (1988) studying E. marginatus growth in the Tunisian coast stands out the necessity in developing qualiquantitative studies gathering grouper stocks from different geographic origins. The presence of big females in a population suggested that not all the females inverted to males. Such big females were not observed in our samples in Santa Catarina, but Barreiros [unpublished results] reported that in 2000, big E. marginatus females were caught in the Azores, weighing over $18 \mathrm{~kg}$ (approximately $950 \mathrm{~mm})$.

The reproductive characteristics of other three hermaphrodite grouper species studied by Coleman et al. (1996), and Sluka AND Sullivan, (1988) showed that these characteristics may affect stocks sustainability. Nowadays it is known that some protogynous stocks may be far more vulnerable to fishing than are comparable gonochoristic stocks (Schaaf and Huntsman, 1994; Musick et al., 2001; Coleman et al., 2001).

Many reef fishes are known to aggregate in large numbers at specific times and places to reproduce. Grouper stocks, as in other serranids, were typically the first reef fish stocks to collapse in response to increasing fishing pressure (Johannes, 1998). In the case of groupers, spawning aggregations have been completely obliterated by overfishing at a number of locations in the Atlantic and the Pacific oceans (Johannes et al., 1999). E. marginatus aggregation sites are known at a few places, such as the Medes Islands Marine Reserve, Spain (Zabala et al., 1997a, 1997b), off Lampedusa Island, Mediterranean Sea (Marino et al., 2001), and the National Park of Port-Cros, France (Chauvet AND Francour, 1991).

In Brazil, these aggregation sites are supposed to exist based on information obtained from fishermen, in their reports of large catches, up to $400 \mathrm{~kg}$ [pers. com.] in a few days of diving in the same area. Little information is known about such important sites in Santa Catarina. Diving centers, operating in the Arvoredo Biological Marine Reserve along the year reported a higher abundance of $E$. marginatus in a single summer week at a diving point north of Deserta Island. Efforts should focus to discover the aggregation sites at Santa Catarina's coast, once mature, juveniles and post-larvae of E. marginatus are found in the studied area. In the Mediterranean area, specific fishery statistics for this species are not available (Marino et al., 2001), and $E$. marginatus is believed to be overexploited in most Mediterranean areas (Bruslé and Bruslé, 1976; Chauvet, 1991; Zabala et al.,1997b). To avoid future stock depletion of this important resource in Santa Catarina's waters, the detection of aggregation sites is vital for the development of a management plan considering spawning aggregations (which should be taken into consideration when delineating marine protected areas) and also groupers minimum capture-size. Alternatively, establishing fishing closures during the brief annual spawning aggregation periods might be an effective approach to protect this valuable resource. 


\section{RESUMO}

Este trabalho trata sobre a biologia reprodutiva da garoupa verdadeira, Epinephelus marginatus (Lowe, 1834) um peixe teleósteo pertencente à família Serranidae, hermafrodita protogínico e característico do litoral rochoso, que vive desde águas rasas até os $200 \mathrm{~m}$ de profundidade. As amostragens foram realizadas nas ilhas que compõem a Reserva Biológica Marinha do Arvoredo (SC) e ilhas costeiras próximas da região de Florianópolis entre março de 1998 e maio de 2000. Dados de coletas de juvenis em poças de marés foram utilizados visando relacionar a sua ocorrência nestes ambientes com o período de pósreprodução. Procedeu-se à análise histológica de 109 exemplares, a partir da qual foram descritas as alterações histológicas nas gônadas ao longo do seu ciclo sexual e foram estabelecidas as escalas de maturação. Desta forma determinou-se um tamanho de primeira maturação para as fêmeas $\left(\mathrm{L}_{50}=470 \mathrm{~mm} ; \mathrm{r}^{2}=0,99\right)$. O comportamento dos valores dos índices calculados (Índice Hepatossomático (IHS) e Índice Gonadossomático (IGS)) elucidou um período reprodutivo com maturação das gônadas ao longo dos meses de primavera, vindo a desovar na estação do verão, sendo nítida a recuperação do fígado (elevação do IHS) no outono, pós reprodução. Calculou-se também a relação peso comprimento $\mathrm{P}=9 \cdot 10^{-6}$. $\mathrm{CT}^{3,1149}\left(\mathrm{r}^{2}=0,998 ; n=246\right)$.

\section{ACKNOWLEDGMENTS}

This paper is dedicated in memory of Gabriel Fonseca Lima. A special thank to Thalassar Diving group for logistics and homepage:

www.cttmar.univali.br/ garoupa We would like to thank Mr. Vitor da Silva Dutra, Manager of Arvoredo Biological Marine Reserve, Mr. Ten. William Wallace, Cb. Murilo and Sd. Vanilson, from the Environmental Police, who kindly provided logistics in Arvoredo Island. We are also grateful to all the Laboratório de Ciências Ambientais staff for support in field and in the laboratory. A special thanks to Paula Lourinho, DOP's staff for data analysis and Susana Mendes for the final revision of the paper.

\section{REFERENCES}

Azevedo, J. M. N.; Rodrigues, J. B.; Mendizabal, M. and Arruda, L. M. (1995), Study of a sample of dusky groupers, Epinephelus marginatus (Lowe, 1834), caught in a tide pool at Lajes do Pico, Azores. Boletim do Museu Municipal do Funchal, suppl. 4, 55-64.

Barreiros, J. P. (1995), Aspectos do comportamento e reprodução do mero Epinephelus marginatus (LOWE, 1834) nos Açores. Angra do Heroísmo, 1995. Tese (Mestrado em Etologia Animal) Departamento de Ciências Agrárias, Universidade dos Açores. 95 pp.

Barreiros, J. P. (1998), Inversão sexual em Epinephelus marginatus (Lowe, 1834) (Pisces: Serranidae, Epinephelinae) nos Açores. Revista Portuguesa de Zootecnia, 5 : (1), 81-90.

Barreiros, J. P. and. Santos, R. S (1998), Notes on the food habits and predatory behaviour of the dusky grouper, Epinephelus marginatus (Lowe, 1834) (Pisces: Serranidae) in the Azores. Arquipélago. Life and Marine Sciences, 16A, 29-35.

Bertoncini, A. A.; Barreiros, J. P.; Hostim-Silva, M. and Inez, V. M. (1999), Ictiofauna ocorrente em sistemas intertidais no município de Penha -SC. In: Resumos do XIII Encontro Brasileiro de Ictiologia. Universidade Federal de São Carlos - SP. 209 pp.

Bou-Ain, A. (1984), Contribution à l'étude des Serranidés des côtes tunisiennes. Thèse Doctorat d'Etát, Unive. Tunis. 393 pp.

Bouchereau, J. L.; Body, P. and Chauvet, C. (1999), Growth of the dusky grouper Epinephelus marginatus (Linnaeus, 1758) (Teleostei, Serranidae), in the Natural Marine Reserve of Lavezzi Islands, Corsica, France. Scientia Marina, 63 : (1),71-77

Bruslé, J. and Bruslé, S. (1975), Ovarian and testicular intersexuality in two protogynous mediterranean groupers, Epinephelus aeneus and Epinephelus guaza. In: REINBOTH, R. (Editor) Intersexuality in the Animal Kingdom. Springer Verlag, N.Y.

Bruslé, J. and Bruslé, S. (1976), Contribution à l'étude de la reproduction de deux espèces de merous (Epinephelus aeneus et Epinephelus guaza) des côtes de Tunisie. Revue des Travaux de l'Institut de Péches Maritimes de Nantes. 39 : (3), 313-320.

Chauvet, C. (1981), Calcul par Otolimetrie de la relation Long. T - Age d'Epinephelus guaza (Linnaeus, 1758) de la Côte Nord de la Tunisie. Rapport de la Commission Internationale de la Mer Méditerranée, 27, 103-106.

Chauvet, C. (1988), Étude de la croissance du mérou Epinephelus guaza (Linnaeus, 1758) des cótes tunisiennes. Aquatic Living Resources, 1, 277-288. 
Chauvet, C. (1991), Statut d' Epinephelus guaza (Linnaeus, 1758) et éléments de dynamyque des populations méditerranéenne et atlantique. In: Boudouresque, C.; Avon, F. M. and Graves, V. (eds.). Les Espèces Marines à Protéger en Mediterranée, GIS Posidonie publ., France. pp. 255-275.

Chauvet, C. and Francour, P. (1991), Les Mérous Epinephelus guaza du Parc National de Prot-Cros (France): aspects Socio-Demographiques. Bulletin de la Societé Zoologique de France, 114 :(4), 5-13.

Coleman, F.C.; Koening, C.C. and Collins, L.A. (1996), Reproductive stiles of shallow-water groupers (Pisces: Serranidae) in the eastern gulf of Mexico and the consequences of fishing spawning aggregations. Environmental Biology of Fishes, 47, 129-141.

Coleman, F. C.; Koenig, C. C.; Huntsman, G. R.; Musick, J. A.; Eklund, A. M.; McGovern, J. C.; Chapman, R. W.; Sedberry, G. R. and Grimes, C. B. (2001), Long-lived reef fishes: the grouper-snapper complex. Fisheries, 25 : (3), 14-20.

Derbal, F. and Kara, M. H. (1996), Alimentation estivale du merou, Epinephelus marginatus (Serranidae), des côtes est Algeriennes. Cybium, 20 : (3), 295-301.

Garcia, V. (1996), Estudio de la biología y possibilidades de cultivo de diversas espécies del genero Epinephelus. Ph. D. Thesis Universitat de Barcelona. Barcelona. 297 pp.

Gibson, R.N. (1967), The use of the anaesthetic quinaldine in fish ecology. Journal of Animal Ecology, 36, 295-301.

Gibson, R. N. (1999), Methods for Studying Intertidal Fishes. In: Horn, M. H.; Martin, K. L. M. and Chotkowski, M. A. (eds.), Intertidal Fishes - Life in Two Worlds. Academic Press, San Diego, USA. xiv $+399 \mathrm{pp}$.

Heemstra, P. C. and Randall, J. E. (1993), Groupers Of The World (Family Serranidae, Subfamily Epinephelinae). An annotated and illustrated catalogue of the grouper, rockcod, hind, coral grouper and lyretail species known to date. FAO Fisheries Synopsis, 16 : (125), 382.

Johannes, R. E. (1998), The case for data-less marine resource management: examples from tropical nearshore fisheries. Trends in Ecology and Evolution, 13, 243-246.

Johannes, R. E.; Squire, L.; Graham, T.; Sadovy, Y. and Renguul, R. (1999), Spawning Aggregations of Groupers (Serranidae) in Palau. The Nature Conservancy Marine Conservation Research Series Publication; 1.144 pp.

Kara, M. H. and Derbal, F. (1995), Morphométrie, croissanse et mortalité du merou, Epinephelus marginatus (Serranidae), des côtes de l'est Algérien. Cahiers de Biologie Marine, 36, 229-237.
Lourinho, P. C. M. (1998), Estudo da Reprodução da Garoupa Serranus atricauda (Günther, 1874) dos Açores. Tese de Licenciatura em Engenharia Zootécnica. Universidade dos Açores, Departamento de Ciências Agrárias. 58 pp.

Marino, G; Azzurro, E.; Massari, A.; Finoia, M. G. and Mandich, A. (2001), Reproduction in the dusky grouper from the southern Mediterranean. Journal of Fish Biology, 58, 909-927.

Medeiros, R. P.; Vizinho, S. C; Macedo, C. X. and Polette, M. (1997), Diagnóstico sócio-econômico e cultural das comunidades pesqueiras artesanais do litoral centro-norte do Estado de Santa Catarina. Notas Técnicas da FACIMAR/UNIVALI, 1, 33-42.

Musick, J. A.; Berkeley, S. A.; Cailliet, G. M.; Camhi, M.; Huntsman, G.; Nammack, M. and Warren Jr., M. L. (2001), Protection of marine fish stocks at risk of extinction. Fisheries, 25 : (3), 6-8.

Schaaf, G. R. and Huntsman, W. E. (1994), Simulation of the impact of Fishing on Reproduction of a Protogynous Grouper, the Grasby. North American Journal of Fisheries Management, 14, 41-52.

Silveira, M. P. M. (1999), Ciclo reprodutivo e desenvolvimento ontogenético do linguado Paralichthys orbignyanus (Teleostei: Paralichthyidae) do Sul do Brasil. Dissertação de Doutorado. Fundação Universidade do Rio Grande.

Sluka, R. D. and Sullivan, K. M. (1988), The influence of spear fishing on species composition and size of groupers no patch reefs in the upper Florida Keys. Fishery Bulletin, 96, 388-392.

Tortonese, E. (1986), Serranidae. In: Whitehead, P. J. P; Bauchot, M. L.; Hureau, J. C.; Nielsen J. and Tortonese, E. (eds.). Fishes of the North Atlantic and Mediterranean. FAO, 2, 780-792

Vazzoler, A. E. A. M. (1996). Biologia da reprodução de peixes teleósteos: teoria e prática. Maringá : EDUEM/SBI. 169 pp.

Zabala, M.; Garcia-Rubes, A.; Loisy, P. and Sala, E. (1997a), Spawning behavior of the Mediterranean dusky grouper, Epinephelus marginatus (Lowe, 1834) (Pisces, Serranidae) in the Medes Islands Marine Reserve (NW Mediterranean, Spain). Scientia Marina, 61, 65-77.

Zabala, M.; Loisy, P.; Garcia-Rubes, A. and Gracia, V. (1997b), Social-behavioral context of reproduction in the Mediterranean dusky grouper, Epinephelus marginatus (Lowe, 1834) (Pisces, Serranidae) in the Medes Islands Marine Reserve (NW Mediterranean, Spain). Scientia Marina, 61, 79-89.

Received: July 06, 2001; Revised: October 22, 2001; Accepted: September 11, 2002. 